\title{
The Roles of Auditors in Fraud Detection and Prevention in Nigeria Deposit Money Banks: Evidence from Southwest
}

\author{
Olaoye Clement Olatunji \\ Dada Raphael Adekola \\ Department of Accounting, Ekiti State University, \\ Ado Ekiti, Ekiti State, Nigeria
}

Doi: 10.19044/esj.2017.v13n31p290 URL:http://dx.doi.org/10.19044/esj.2017.v13n31p290

\begin{abstract}
This study examined the impact of auditors captured by risk assessment, system audit and verification of financial report on banking fraud control in Southwest Nigeria. The study employed survey design in which a set of questionnaire was administered on the selected banks in Southwest Nigeria. Multiple regression technique and ANOVA were used for the analysis. The results indicated that the level of fraud control in Nigerian banks during the period covered was low; the result revealed that risk assessment management, system audit and verification of financial reports adopted by the banking industry in Southwest Nigeria limit the fraudulent activities among the Nigerian banks by 35, 13 and 18 percent respectively; the results also showed that audit roles captured by risk assessment, system audit and verification of financial reports were statistically significant in determining the fraudulent act in banking industry in Nigeria as revealed by $\left(\mathrm{T}_{\text {cal }} 4.446,2.251\right.$ and $\left.3.708>\mathrm{T}_{\text {tab }}(141)=1.684\right)$. Based on the findings, the study concluded that risk assessment, system audit and financial report verifications are carried out to determine the effectiveness and impact of auditors on fraud control in Nigerian banks which reveals that auditors' roles need to be improved to enhance fraud control in banking industry. The study recommended that auditors should increase the scope of their activities on the efficiency of banks internal control system, risk assessment and system audit as this will enhance the detection of fraudulent activities. Also, management of banks should ensure strict compliance with their respective internal control system.
\end{abstract}

Keywords: Auditor, risk assessment, system audit, financial report, fraud, auditor 


\section{Introduction}

The role of auditors in fraud control and monument is essential. Fraud has been one of the most problematic and unsolvable matter for business all over the world for a long time; however, there has been much more attention and research dedicated to the topic after the scandals such as Enron, WorldCom and others. Frauds have led to loss of huge amount of money in the banking industry and nation's economy in general (Fatoki, 2015). Researchers have discovered that fraud contributed drastically to the financial distress of poor performance of many banks in Nigeria (Austin, 2011). According to Olorunsegun (2010), fraud is a major challenge of banking industry and this makes all banks vulnerable and distress. The management of each bank spends their hard-earned money to curtail it occurrence. Moreover, it puts question marks on the integrity of the employees and management of the banks and also gives rise to absolute loss of customers' confidence in banking. Adeyemo (2012) asserted that banking frauds are made possible with insiders or staffs collaboration. The management and staffs of every bank are expected to carry out their responsibilities with ultimate sincerity of purpose devoid of fraudulent practices to enhance public gain, trust and goodwill. Besides the role played by banking industry in growth and development of the nation economy, fraud goes a long way in depriving the economy of the necessary funds required for sound economic activities. It was discovered that the actions taken by the management of the banks in the aftermath of fraud cases are insufficient in stopping another fraud from been perpetrated. In a study carried out by Onwujiuba (2013), it was revealed that the managements of banking industry are not putting up enough measures that can prevent and control banking frauds, hence, the reason for incessant fraudulent practices in Nigeria.

Adeyemi and Uadiale (2011) opined that the existing duties and responsibilities of auditors are inadequate and are not clearly defined. Also, the expectation of the people on the issues of the auditors' responsibilities in detecting and curtailing fraudulent act are high. As a result, a significant number of people or respondents believed that auditors' responsibilities should be widened. Abu-Saeed and Kabir (2012) revealed that the internal audit unit needs to be alive in discharging their responsibilities and the need to acquire basic or necessary knowledge that can engender fraud prevention in the banking industry. Sorunke (2016) observed that internal audit unit did not contribute significantly to fraud prevention and control in reality. The question is, what then, is the role of auditors in the prevention of fraudulent activities in Nigeria's banking industry? In view of this, the study was carried out to investigate the impact of auditor on bank fraud in Nigeria. 


\section{Conceptual Review \\ Banking}

Banking represent the means and methods through which funds are obtained, controlled, allotted and used (Ciuhureanu, Balteş \& Brezai, 2009), a bank can be associated with a financial service conglomerate which is able to provide basic financial services and other functions within the economic, political, legal and international environment that determines its profit and expansion opportunities, interest rates, exchange rates and the particular resources a bank need (Drigă, 2006). The efficiency and effectiveness of the banking system is a key determinant of the economy growth of a nation (Dura \& Drigă, 2015). The existence of an effective banking industry is a panacea to growing any nation's economy. The pivot of any economic development is the financial sector through its creditable roles in intermediating funds/capital from the surplus units to deficit units. These two laudable and reliant functions bring the banks face to face and in contact with the public who come to obtain their services. However, the roles of mobilizing deposit (surplus) and directing such deposit to the deficit sectors of the economy makes DMBs to attend to a large number of customers who they may not, most of the time, personally know, or whose identity may not be immediately known to the banks. This shows that banks may not be familiar with the true identity of these customers all of whom either have genuine/honest or fraudulent intentions (Dimejesi, 2014).

\section{Fraud}

The terms "fraud" has received attention and different definitions from different scholars, researchers and authors. What is very peculiar to the definitions is that the concept has been associated with embezzlement, financial misstatement and misappropriation, extortion, illegal amassing of wealth through dubious means, act of deception, bribery, false representation, theft, concealment of material fact etc. According to Adeyemo (2012), fraud is defined as "any illegal act characterized by deceit, concealment or violation of trust. These acts are not dependent on the application of threat or violence or of physical force. On the other hand, Mutesi (2011) defined fraud as "any premeditated act of criminal deceit, trickery or falsification by a person or group of persons with the intention of altering facts in order to obtain undue personal monetary advantage. Osisioma (2013) defined fraud as all the multifarious means which human ingenuity can devise and are resorted to by one individual to get any advantage over another. It includes all surprise, trick, cunning, dissembling and unfair ways by which another is deceived. Fraud covers a plethora of corporate crimes like embezzlement, larceny, theft, misappropriation of assets, among others. Penny (2002) explains fraud as an illicit financial gain 
for the fraudster or loss for the victim while Mahinda (2012) introduces a different concept to the definition of fraud. He argues that the menace occurs as a result of a person in position of trust or accountability who advances his own personal interests at the expense of the public interests through digressing from the set standards and rules.

\section{Types of Fraud}

Fraud in the banking is varies widely in nature, character and method of perpetration. Olaoye, Dada and Adebay (2014) categorize perpetrators into three namely; management of the banks (otherwise referred to as management fraud), insider (employee), outsider (customers and noncustomers) and insider/outsider. These are explained thus: Management Fraud is a kind of fraud frequently committed by management staff of a reporting entity, which comprises the director, general managers, and managing directors to mention but a few. As management fraud is normally committed by persons in positions of trust, they have the authority to override internal controls (Singleton, Bologna \& Lindquist, 2006). According to Ahmed et al., (2014) the category of victims of management frauds are investors and creditors, and the medium for perpetrating the fraud is financial statement. Insiders/employees frauds are the frauds perpetrated by the employees of the bank or organization is also known as nonmanagement fraud. According to Olaoye (2009) it is the fraud perpetrated to the detriment of the organization and generally it is for the direct or indirect benefit of an employee. Boniface (1991) identifies some of the typical manifestations of employee's frauds in the banks to include: Cash thefts from the tills by banks' staff, forging of customer's signature with the intention of illegally withdrawing money from the account with the bank, use of forged cheques to withdraw money from the customer's accounts, opening and operating of fictitious account to which illegal transfers could be made and false balance credited, lending to fictitious borrowers effected through fictitious account opened at a branch, claiming of overtime for hours not worked, suppression of cash/cheques; fund diversion and computer fraud. Outsiders' fraud is frauds perpetrated by customers and non-customers to the detriment of the banks. This class of fraud as describe by Perspectives on the Nigerian Financial Safety-net (NDIC 2009) includes: advance fee fraud ("419") that usually involves an agent approaching a bank with an offer to access large funds for services purportedly rendered or contracts executed. According to Olaoye, et al (2014), the collaboration of an accomplice is sought through the agent who must receive a fee or commission "in advance". As soon as the agent collects the fee, he disappears, and the funds never get to the bank. This is popularly known as " 419 " in Nigeria. Lastly, Outsiders/insiders fraud, this is the types of fraud committed by outsiders 
(customers/non-customers) of the bank with the effort of an insider (bank staff). For this type of frauds to be successful, there must be an insider providing necessary information and other logistic in secret (Olaoye, et al 2014).

\section{Causes of Bank Fraud}

NDIC (2009) groups the causes of bank fraud into three namely; institutional, social and individual. Institutional factors are conditions unconsciously created by institutions that allow fraud to flourish. In such institutions, a lot of loopholes are allowed to exist which fraudsters easily identify and exploit to commit their acts. Olaoye, Dada \& Adebayo (2014) highlighted here under the common institutional causes of fraud: inadequate internal control, inexperience of staff/inadequate staff training, employment disaffection, poor management, banks reluctance to report fraud due to the perceived negative publicity or image from the public, inadequate training and re-training, failure to engage in regular call-over, employees refusal to abide by laid-down procedures without any penalty or sanction, automation and computerization and disregard to know your customer (KYC) rules. Social factors such as societal values, placing of high value on accumulation of wealth by the society without regard for the source, promotion of nepotism in office where by only those with people in "high places" or high deposit or people who have relations or people holding sensitive political positions are favored, thereby placing less emphasis on professionalism, poor economy and slow legal process are part of social factor that influence fraud (Olaoye, et al. 2014; Akindele 2011 \& Adewunmi 1996); Individual factors are factors that pertain to the person, that is, those that are peculiar to the individual and may encourage him to live a fraudulent life. These factors include: Biological make-up - e.g. poor moral upbringing, criminal background, insatiable appetite for adventure- criminal or otherwise, wrong choice of friends or mentors, crime fathers, friends or parental influence to slow down investigation and weak mind.

\section{Auditors Role}

According to Awe (2005), Oladipupo (2005) and Babatunde (2002) Auditor is an independent person appointed by the shareholders to examine the records and financial statements of an organization for the purpose of forming an opinion on the accuracy and correctness of the financial statements. When planning and performing audit procedures and in evaluating and reporting the results thereof, the auditors should consider the risk of material misstatements in the financial statements, including those resulting from fraud or error. 
Objective of an audit: The main objective of an audit of financial statements is to enable the auditor to express an opinion whether the financial statements are prepared, in all material respects, in accordance with an identified financial reporting framework and that the financial statements give a true and fair view or present fairly, in all material respects of the financial results and state of affairs of the client entity (Babatunde 2002). Although the auditor's opinion enhances the credibility of the financial statements, the user cannot assume that the opinion is an assurance as to the future viability of the entity nor the efficiency or effectiveness with which management has conducted the affairs of the entity.

The subsidiary objectives are, as described by (Awe, 2005; Oladipupo, 2005 and Babatunde, 2002): to detect errors and fraud; to prevent errors and fraud; and to help the client to improve upon his accounting and internal control systems. It must be emphasized that audit is not designed to detect errors, fraud and significant weaknesses in the client's systems but the audit work should be carried out in such a manner as to be able to expose errors, frauds and weaknesses (if they exist). In accordance with ISA 200, the auditor shall maintain professional skepticism throughout the audit, recognizing the possibility that a material misstatement due to fraud could exist, notwithstanding the auditor's past experience of the honesty and integrity of the entity's management and those charged with governance. (Ref: Para.A7-A8). Auditors shall be responsible for the following: Prevention: though, it is not the auditor's function to prevent fraud and error, the fact that an annual audit assignment is carried out may create fear in the heart of the fraudster, hence, act as a deterrent. Risk Assessment: risk assessment is the "process of assessing, understanding and managing risks that the entity is inevitably subject to in attempting to achieve its corporate objectives (CIMA, 2005). When planning the audit, as stipulated in International Standard on Auditing (ISA 315 and SAS No. 82,) an auditors should assess the risk that fraud or error may cause the financial statements to contain material misstatements ISA 315. Though, Porter (1977) concluded that the primary objective of an audit in the pre-1920 was to uncover fraud. However, according to Oyinlola (2010) the primary objective of an audit has changed to verification of accounts and expression of opinion on the financial statement. This is most likely due to the increase in size and volume of companies' transactions which in turn made it unlikely that auditors could examine all transactions. The existence of a fraud risk assessment and the fact that an auditor is articulating its existence may even deter would-be fraud perpetrators (IIA, AICPA, \& ACFE). Furthermore, Oyinlola (2010) claims that auditors are required to be more proactive in searching for fraud during the course of an audit assignment. Their duties now include considering incentives and an opportunity presented to potential fraudsters, 
as well as rationalizations that the fraudulent act is justified. Auditors are also expected to inquire more closely into reasons behind such matters as, for example, errors in accounting estimates, unusual transactions that appear to lack business rationale, and a reluctance to correct immaterial errors discovered by the audit. Detection: Based on their risk assessment, according to ISA 330, the auditors should design audit procedure so as to have a reasonable expectation of detecting misstatements arising from fraud or error which are material to the financial statements. The auditors seek sufficient appropriate audit evidence that fraud and error which may be material to the financial statement have not occurred or that, if they have occurred, the effect of fraud is properly reflected in the financial statements or the error is corrected. Therefore, auditors shall report the fraud detected to those saddled with entity governance on time. He shall also report to those charged with the governance of the entity any other matter related to fraud (Babatunde, 2009). Auditor shall report to: members of the company, management of the company, and Third parties.

\section{Literature Review}

Salameh, Al-Weshah, Al-Nsour and Al-Hixain (2011) examined the impact of internal audit structures and perceived effectiveness of fraud prevention in Canada using t-test. Based on their findings they concluded that fraud could be prevented with effective internal audit units. Arivid and Cornelia (2012) assessed the impact of fraud prevention on bank-customer relationships" using least square method and discovered another dimension to the issue of fraud when they found a positive association between customer familiarity with and knowledge about fraud prevention and the quality of customer relationship as a measured of satisfaction, trust and commitment. Linder Bresster (2010) investigated the role of forensic accountant in fraud investigations: importance of Attorney and Judge's perception and concluded that training of auditors is important for fraud prevention. He argues that this will make them to become experts in fraud prevention. However, Chen, fifth, Gao and Rui (2006) assessed the ownership structure, corporate governance and fraud in China using table and percentage. They concluded that a large number of outside directors contributed to financial statement fraud. The large proportion of outside directors would be helpful in monitoring the firm's activity to reduce fraud. Reinstein, Moehrlr and Moehrlr (2006) adopted Kohlberg Model in their work to investigate crime and punishment in the marketplace: Accountants and Business executives repeating history and concludes that financial statement fraud begins with financial and morale problems in the banks but Zhang, Zhou and Zhou (2007) disclosed in their study on audit committee quality, auditor independence, internal control weaknesses and effective role 
of the audit committee contributed to better internal control of the industry. In addition to the competence of the audit committees are also expected to be independent in overseeing the bank's internal control. The audit committee is also responsible for ensuring that management does not engage in fraudulent conduct.

Agyei, Kusi-Aye and Owusu-Yeboah (2013) assessed Audit Expectation Gap in Ghana using regression analysis and found that there exists expectation gap concerning auditor's responsibility relating to fraud detection and prevention. The work corroborates Bogdanoviciute (2011) who empirically reviewed Audit Expectation Gap: The case of Lithuania and Saeidi, (2012) who empirically examined audit expectations gap and corporate fraud in Iran. Fadzil, Haron and Jantan (2005) assessed internal auditing practices and internal control system using t-test statistic. They discovered that the professional proficiency of internal auditors influenced the effectiveness of the internal audit function on fraud detection.

Zacharia, Jerry and Danjuma, (2012) examined the adequacy of external auditing on fraud in Nigerian commercial banks. The study was done using analysis of variance and they found that external audit is not adequate in detecting fraud. Adeoti (2011) appraised the impact of Automated Teller Machine (ATM) on Frauds in Nigeria using chi-square and discovered that bankers and customers have roles to play in curtailing fraudulent act in our banks. He established that ATM helps in preventing fraud. Kabri (2009) evaluated the role of forensic auditing in combating fraud in the Nigerian banking sector using Main-Whitney U-Test. The study revealed the need for modifying regulatory framework in Nigeria by using macro environmental forces such as regulatory and legal pressure on auditing profession to be more responsive for fraud detection in financial statements. Uchenn and Agbo (2013) assessed the impact of fraud and fraudulent practices on the performance of banks in Nigeria. The study adopted multiple regression method and from the finding it was established that fraudulent activities inflict severe financial difficulties on banks which affects the amount of money available for economic development. Oyinlola (2010) investigated the role of auditors in fraud detection, prevention and reporting in Nigeria. The employed table and percentage discovered that the respondents are very concerned about the problem of fraud and that the duty of auditor is fraud detection.

\section{Research Method \\ Research Design}

This study adopted survey design as a research strategy. The study employed the use of primary data in order to achieve the stated objective of the study. Descriptive and inferential statistical method was adopted in order 
to provide a proficient appraisal of the impact of auditors on bank fraud control in Southwest Nigeria. The population of this study include 22 Deposit Money Banks (DMBs) in Nigeria while data were source from auditors, control officers, operation managers and branch managers or heads of the six selected DMBs in Southwest Nigeria (First Bank of Nigeria Plc., United Bank for Africa Plc., Union Bank Plc., Zenith Bank Plc., Access Bank Plc. and Guaranteed Trust Bank Plc). Data used for this study were obtained using a well structured questionnaire from a sample size of 142 respondents selected from six (6) deposit money bank branches in Southwest Nigeria. The data was analyzed using appropriate descriptive and inferential statistics. The descriptive statistics involved Summary Statistics while regression analysis technique and ANOVA were used as an inferential statistics. Other diagnostics test been carried out includes test for the significant of the estimated parameters using standard error test, T-test and probability test; test for significant of the fitted model using R-square and test for the goodness of fit of the model using F-test statistic.

\section{Model Specification}

The model for the study comprises explanatory variables which are Auditors' roles captured by Risk Assessment-RSKM, System Audit-SYSA and Verification of Financial Reports-VFR while, Fraud Control (FRDC) serve as the dependent variable.

The model for the study is specified as follows:

$F R D C=f(R S K M, S Y S A, V F R)$

$F R D C=a_{o}+b_{1} R S K M+b_{2} S Y S A+b_{3} V F R+\mu$

Where:

$F R D C=$ Fraud Control

$R S K M=$ Risk Assessment

$S Y S A=$ System Audit

VFR = Verification of Financial Reports

$\mathrm{a}_{\mathrm{o}}=$ Constant Parameter

$\mathrm{b}_{1}, \mathrm{~b}_{2}, \mathrm{~b}_{3}=$ Parameters to be estimated

$\mu=$ Error Term

\section{Result and Discussions}

Table 4.1: Descriptive Analysis

\begin{tabular}{|c|c|c|c|c|}
\hline & FRDC & RSKM & SYSA & VFR \\
\hline Mean & 45.28571 & 45.17857 & 44.20626 & 42.93650 \\
\hline Median & 46.00000 & 45.00000 & 43.33300 & 43.33300 \\
\hline Maximum & 50.00000 & 50.00000 & 50.00000 & 50.00000 \\
\hline Minimum & 36.00000 & 37.50000 & 33.33300 & 33.33300 \\
\hline Std. Dev. & 3.473142 & 3.093702 & 3.611245 & 4.305556 \\
\hline Skewness & -0.681673 & -0.214541 & -0.418549 & -0.120181 \\
\hline
\end{tabular}




\begin{tabular}{|c|c|c|c|c|}
\hline Kurtosis & 3.481154 & 2.618656 & 3.801472 & 2.353250 \\
\hline Jarque-Bera & 3.657888 & 0.576686 & 2.350407 & 0.833106 \\
\hline Probability & 0.160583 & 0.749504 & 0.308756 & 0.659316 \\
\hline
\end{tabular}

Source: Researcher's Computation, 2017

Table 4.1 shows the descriptive analysis results of all the activities regarding the roles of auditors in fraud control in Nigeria. The level of fraud control and the roles of auditors were captured by risk assessment, system audits and verification of financial reports. The result reveals that the average rate of fraud control, risk assessment, system audit and verification of financial reports are 45.29, 45.18, 44.21 and 42.94. This result implies that the average level of fraud control in banking industry is low and not encouraging. The risk assessment, system audit and verification of financial reports reveal that the auditors' roles need to be improved to enhance fraud control in banking industry in Nigeria. The maximum and minimum level of fraud control, risk assessment, system audit, verification of financial reports are; 50 and 36, 50 and 37.50, 50 and 33.33 and 50 and 33.33 respectively.

The standard deviation values of $3.47,3.09,3.61$ and 4.31 reveal the rate at which fraud controls, risk assessments, system audit and verification of financial reports have deviated from their respective and expected roles. Also, it was discovered that skewness of fraud control, risk assessment, system audit and verification of financial reports are $-0.68,-0.21,-0.42$ and .012 respectively. This result indicates that the financial variables under consideration are negatively skewed because their distributions have a long tail to the left. However, the kurtosis values $0.481,-0.381,0.801$ and -0.647 respectively measured the extent of peakness of the financial variables. The result reveals that fraud controls and system audit are leptokurtic in nature because the kurtosis coefficient indexes are positive. On the other hand, risk assessments and verification of financial reports are platykurtic in nature because their coefficients of kurtosis are negative. The Jarque-Bera values reveal that the financial variables examined in this study are not normally distributed statistically.

Table 4.2: Reliability Statistics

\begin{tabular}{|c|c|c|}
\hline Cronbach's Alpha & Cronbach's Alpha Based on Standardized Items & N of Items \\
\hline .606 & .655 & 4 \\
\hline
\end{tabular}

Source: Researcher's Computation, 2017

The reliability of the instrument was tested using Cronbach's Alpha test. Cronbach's alpha test is used to investigate the internal consistencies of the research instrument. If the result reveals value between 0.50 and 1.0 for the identified variables then the reliability of the instrument in reasonable term is established to take acceptable decision and conclusion regarding the 
study under investigation. Thus, from the result, it was discovered that the Cronbach's Alpha statistics is 0.61 . This value implies that the research instrument used in the study is 61 percent reliable and desirable in determining the impact of audit role, financial regulatory authorities and professional ethics on fraud control in banking industries in Nigeria.

Table 4.3: Fitted Model using Least Squares Method

\begin{tabular}{|c|c|c|c|l|}
\hline Variable & Coefficient & Std. Error & t-Statistic & Prob. \\
\hline C & 21.34831 & 5.498828 & 3.882338 & 0.0091 \\
\hline RSKM & 0.346672 & 0.077983 & 4.445817 & 0.0000 \\
\hline SYSA & 0.129669 & 0.057619 & 2.250456 & 0.0056 \\
\hline VFR & 0.182077 & 0.049109 & 3.707610 & 0.0003 \\
\hline
\end{tabular}

Source: Researcher's Computation, 2017

From the fitted regression model, it was discovered that a positive linear relationship exists between risk assessment management, system audit, verification of financial reports and fraud control in banking industry in Nigeria. This shows that risk assessment management, system audit and verification of financial reports which captured the auditors' roles have a direct relationship with the fraud control in Nigerian banking industry. The result shows that risk assessment management, system audit and verification of financial reports adopted by the banking industry in Nigeria limit the fraudulent activities among the Nigerian banks by 35, 13 and 18 percent respectively. This result indicates that risk assessment management, system audit and verification of financial reports been carried out in the banking industry in Nigeria are not effective in tackling or controlling the incessant incidence of fraudulent activities. Thus, it implies that there is need for the auditors to be alive to their responsibilities such that financial statements are prepared in accordance with an identified financial reporting framework in such a way that the financial statements give a true and fair view of the financial results and state of affairs of the client entity so that banking fraud in Nigeria can be curtailed.

The statistical significance of the estimated parameters of the model was examined using the standard error test, $t$-test statistic and the probability value. In using standard error test, the rule of thumb is that half of the estimated parameter must be greater than the standard error value in absolute term to establish the statistical significance of the parameter. Therefore, it was discovered from this study that half of the coefficient of the variables or estimated parameters for risk assessment, system audit and verification of financial reports are $0.173,0.065$ and 0.091 respectively which are greater than the standard error values $0.078,0.058$ and 0.049 . Thus, it implies that audit roles captured by risk assessment, system audit and verification of financial reports are statistically significant in determining the fraudulent act in banking industry in Nigeria. In using T-test statistic, the rule is that the 
estimated T-statistic value must be greater than or equal to the T-tabulated value at a given degree of freedom and level of significance that is, $\mathrm{T}_{\text {cal }} \geq \mathrm{T}_{\mathrm{tab}}$ (df). Thus, the $\mathrm{T}$-statistic values 4.446, 2.251 and 3.708 $>\mathrm{T}_{\text {tab }}(141)=1.684$. This implies the statistical significance of risk assessment, system audit and verification of financial reports in examining banking fraud in Nigeria. However, the same result was also discovered using the probability value of the estimated parameters. This is because the probability values $0.000,0.006$ and $0.000<0.05$ establish the statistical significance of risk assessment, system audit and verification of financial reports in curbing the incidence of fraud in Nigerian banking industry.

The test for the theoretical significance of the estimated parameters was examined based on the sign of the estimated parameters. It was discovered from the analysis that risk assessment, system audit and verification of financial reports were positively signed. Thus, the result implies that audit roles captured by risk assessment, system audit and verification of financial reports have direct impact on fraudulent activities in banking industry in Nigeria. This result affirms a priori expectation that auditor's roles are vital to the control of fraudulent incidence in banking industry in Nigeria.

Table 4.4: Test for the Significance of the Model

\begin{tabular}{|c|c|c|c|c|}
\hline Model & $\mathrm{R}$ & R Square & Adjusted R Square & Std. Error of the Estimate \\
\hline 1 & $.736^{\mathrm{a}}$ & .542 & .483 & 3.29025 \\
\hline
\end{tabular}

Source: Researchers' Computation, 2017

The test for the significance of the model also known as the test for the coefficient of determination of the model was presented in table 4. It is the proportion of variation in the dependent variables that can be explained by the explanatory variables. This test was carried out using R-Square statistic. However, the R-Square value 0.54 implies that 54 percent variation in level of fraudulent act occurring in the banking industry in Nigeria can be explained by financial auditor roles captured by risk assessment, system audit and verification of financial reports. The result further reveals that the extent of the relationship that exists between audit roles and fraud control is 0.74. This implies that there is a strong correlation between the auditors' roles and fraudulent acts in banking industry. Thus, the need for an improvement of internal control system for effective service delivery; training and retraining of staff to acquire more relevant knowledge that can enhance better management thereby, leading to a drastic reduction in fraudulent acts in Nigerian banking industry. 
Table 4.5: Test for the overall significance of the model

\begin{tabular}{|c|c|c|c|c|c|}
\hline Model & Sum of Squares & Df & Mean Square & F & Sig. \\
\hline Regression & 172.945 & 5 & 34.589 & 5.937 & $.000^{\mathrm{b}}$ \\
Residual & 209.736 & 136 & 5.826 & & \\
Total & 382.681 & 141 & & & \\
\hline
\end{tabular}

a. Dependent Variable: FRDC

b. Predictors: (Constant), RSKM, SYSA, VFR

Source: Researcher's Computation, 2017

The test for the overall significance of the model is also known as the test for the goodness of fit of the model which was presented in table 4.5. The test was done using F- statistic and the probability of F-statistic. The result shows that the F-statistic value 5.937 is greater than the F-tabulated value 2.45 at 95 percent confidence level. Also, the probability of F-statistic $0.000<0.05$ the error margin allowed in the estimation of model. It was concluded based on this fact that the model is appropriate and adequate for determining the impact auditor roles captured by risk assessment, system audit and verification of financial reports on fraud control in Nigeria banking industry. Therefore, a viable internal control system through responsive auditor's role and guidelines are good, reliable and acceptable for determining the fraudulent activities in banking industry in Nigeria.

Table 4.6: Test for equality of mean among the variables

\begin{tabular}{|c|c|c|c|c|}
\hline Method & Df & Value & Probability & \\
\hline Anova F-statistic & $(5,562)$ & 5.065579 & 0.0002 & \\
\hline Friedman's Test & $(5,520)$ & 25.401 & 0.000 & \\
\hline Cochran's Test & $(5,520)$ & 25.401 & 0.000 & \\
\hline F- Test & $(5,520)$ & 5.642 & 0.000 & \\
\hline \multicolumn{5}{|c|}{ Analysis of Variance } \\
\hline Source of Variation & Df & Sum of Sq. & Mean Sq. & \\
\hline Between & 5 & 416.5528 & 83.31056 & \\
\hline Within & 562 & 4045.815 & 16.44640 & \\
\hline Total & 567 & 4462.368 & 17.77836 & \\
\hline
\end{tabular}

Source: Researcher's Computation, 2017

Table 4.6 presents the test for the equality of mean among the variables under investigation in this study. The test was carried out to show whether the impact of auditor's roles in curbing fraudulent activities in banking industry in Nigeria were the same or not. This test is done using Fstatistic, Friedman's Test and Cochran's Test. The probability values of Fstatistic $=0.000<0.05$, Friedman's statistic $=0.000<0.05$ and Cochran's statistic $=0.000<0.05(0.05=$ error margin $)$ reveal that the contributions of risk assessment, system audit and verification of financial reports towards 
fraud control in Nigerian banking industry are not the same. Thus, as the activities are different, the impacts or the contributions are also different.

\section{Conclusion and Recommendations}

Based on the findings of the study it was concluded that the roles of auditors in theory and practice on fraud control which is the integrated set of activities to prevent, detect, respond and monitor fraud in the financial world cannot be overemphasized even with the pervasiveness of fraud incidences in the contemporary times. Risk assessment, system audit and financial report verifications are carried out to determine the effectiveness and impact of auditors on fraud control in Nigerian banks which reveals that auditors' roles need to be improved to enhance fraud control in banking industry. The study recommended that auditors should increase the scope of their activities on the efficiency of banks internal control system, risk assessment and system audit as this will enhance the detection of fraudulent activities. Also, management of banks should ensure strict compliance with their respective internal control system.

\section{References:}

1. Abu-Saeed, M. and Kabir, T. H. (2012). The role of internal audit unit in fraud prevention in

Government owned Hospitals in a Nigeria. IOSR Journal of Business and Management. 2(1). 3944

2. Adeoti, J.A. (2011). Automated Teller Machine (ATM) Frauds in Nigeria: The Way Out. Journal of Social Sciences.27(1). 5358

3. Adewumi W. (1996): Fraud in Banks - An Overview. Landmark Publication Ltd. Lagos

4. Adeyemi, S.B., and Uadiale, O.M. (2011). An empirical investigation of the audit expectation gap in Nigeria. African Journal of Business Management, 5(19). 7964-7971.

5. Adeyemo, K.A. (2012). Frauds in Nigerian Banks: Nature, DeepSeated Causes, Aftermaths and Probable Remedies. A Mediterranean Journal of Social Sciences. 3(2). 279-289

6. Agyei, A., AYE- Kusi, B and Owusu-Yeboah, E.(2013) An Assessment of Audit Expectation Gap in Ghana. International Journal of Academic Research in Accounting, Finance and Management Sciences. 3(4). 112-118

7. Ahmed,I., Madawaki, M. D. and Usman, F. (2014). Managing Bank Fraud and Forgeries Through Effective Control Strategies. A Case of Central Bank of Nigeria, Gombe Branch. International 
Journal of Business and Management Invention. 3(4).7-17 www.ijbmi.org

8. Akindele. R.I. (2011). Fraud as a Negative Catalyst in the Nigerian Banking Industry. Journal of Emerging Trends in Economics and Management Sciences (JETEMS) 2(5). 357-363

9. Arvid,O.I.H and Cornelia, B. (2012). The Impact of Fraud Prevention on Bank-Customer Relationships. International Journal of Bank Marketing. 30(5). 390-407

10. Austin, I.I. (2011). The Impact of Regulation and Supervision in the Nigeria Commercial Banks. P.hd thesis submitted to St. Clements University in partial fulfillment of the requirements for the award of Ph.d in financial management. (Unpublished)

11. Awe O. I. (2005). The Theory and Practice of Auditing. Adeyemo Publishing House, Akure, Nigeria

12. Babatunde, G. (2009). Precipitating factors in fraud and criminal motivation. International Journal of Bank Marketing, 10(3), 232250

13. Babatunde M. A. (2005). Practical Auditing. Al-Huda EducationalPublishers.Osogbo, Nigeria.

14. Boniface, C. (1991). Fraud in the banking industry. The Nigerian Banker Oct.- Dec.22\&23.CIBN Press.

15. Ciuhureanu A.T., Balteş N. and Brezai L. (2009). The Financial Management's Role in Modern Organizations. Interferences and Differences Between the Management of the Accounting Activity and the Financial Management. Anale. Seria Ştiinţe Economice. Timişoara, XV.597-600

16. Chen, G., Fifth, M., Gao, D.N., and Rui, O.M (2006). Ownership structure, corporate governance and fraud: Evidence from China, Journal of Corporate Finance, 12(3), 424-448.

17. Dimejesi T. I. (2014). Effective Internal Control of Frauds in Banks. (MBA) a project report presented to the Department of Banking and Finance, Nnamdi Azikiwe University, Awka, Anambra. (Unpublished)

18. Drigă I. (2006). The Role of the Banking System in the Sustainable Development of the Economy. Annals of the University of Petroşani, Economics. 6.55-60

19. Dura, C. and Drigă, I. (2015). The Financial Sector and the Role of Banks in Economic Development. Annals of the University of Petroşani, Economics 16. 598-603

20. Fadzil, F.H., Haron, H. and Jantan, M.(2005) Internal auditing practices and internal control system, Managerial Auditing Journal, 20(8), 844-866 
21. Fatoki, O.(2015) The Financing Options for New Small and Medium Enterprises in South Africa' Mediterranean Journal of Social Sciences 5(20), 748-755

22. Kabri, T.H. (2009). The role of forensic Auditing in Combating Fraud in the Nigerian Banking sector. Bayero Business Review. 3(2). 23-34

23. Linda Bresster (2010). The role of Forensic Accountant in Fraud Investigations: Importance of attorney and Judge's Perception. Journal of Finance and Accountancy. 3(2). 1-9

24. Mahinda, C. G. (2012). Determinants of Occupational Fraud in Commercial Banks in Kenya. Journal of Modern Accounting and Auditing, 2(3). 2178-2183

25. Mutesi, J. (2011). Information Sharing, Risk Management and Financial Performance of Commercial Banks in Uganda. Journal of Emerging Issues in Economics, Finance and Banking (JEIEFB), 2(2)

26. NDIC. Nigeria Deposit Insurance Corporation (2009) "Perspectives on the Nigerian Financial safety-net".

27. Oladipupo, A.O. (2005). Auditing and Investigations: Theory and Practice. Mindex Publishing Company ltd, Benin City.

28. Olaoye, C. O. (2009). Impact of Internal Control System in Banking Sector in Nigeria. Pakistan Journal of social science, 6(4). 181189

29. Olaoye, C.O., Dada, R.A. and Adebayo, A.O. (2014). Analysis of Frauds in Banks: Nigeria's Experience. International Journal Of Innovative Research \& Development. 3(1)

30. Olorunsegun, S. (2010). The Impact of Electronic Banking in Nigeria Banking System. MBA Research Project Submitted to the Department of Management Science, Faculty of Engineering and Technology, Ladoke Akintola University of Technology, Ogbomoso, Oyo State, Nigeria. Unpublished.

31. Onwujiuba, M. (2013). Overview and Impact of fraud in the commercial banks in Nigeria (A case study of first bank of Nigeria PLC). International Journal of Research in Management, Economics and Commerce, 2(3).

32. Osisioma B.C., (2013). Combating Fraud and White Collar Crimes: Lessons from Nigeria, NIM (Chartered).

33. Oyinlola, A.O. (2010). The Role of Auditors in Fraud Detection, prevention and Reporting in Nigeria. Library Philosophy and Practice (e-journal). http://digitalcommons.unl.edu/libphilprac/517

34. Penny J. (2002). Corporate Fraud: Prevention \& Detection, London: Tolley. 
35. Reinstein, A. Moehrlr, S.R and Moehrlr, J.R. (2006) Crime and punishment in the marketplace: Accountants and business executives repeating history. Managerial Auditing Journal, 21 (4), 420-435

36. Saeidi, F. (2012). Audit expectations gap and corporate fraud: Empirical evidence from Iran. African Journal of Business Management, 6(23), 7031-7041. doi: 10.5897/AJBM12.382

37. Salameh R., Al-Weshah G., Al-Nsour M., and Al-Hixain A (2011). Alternative Internal Audit Structures and Perceived Effectiveness of Internal in Fraud Prevention: Evidence from Jordanian Banking Industry. Canadian Social Science. 7(3). 40-50.

38. Singleton T, S., Bologna J. and Lindquist R. J. (2006) Fraud auditing and forensic accounting, 3rd edn. Wiley, Toronto.

39. Sorunke, O. A. (2016). Internal Audit and Fraud Control in Public Institutions in Nigeria: A Survey of Local Government Councils in Osun State. International Journal of Academic Research in Business and Social Sciences, 6(2). 153-158

40. Uchenna, C and Agbo, J.C. (2013). Impact of Fraud and Fraudulent Practices on the Performance of Banks in Nigeria. British journal of art and social sciences. 15(1)

41. Zachariah P, Jerry M and Danjuma I.(2012). Assessment of the Adequacy of External Auditing in Disclosing Fraud in Nigerian Commercial Banks. Research Journal of Finance and Accounting. 3(6). 149-157. www.iiste.org

42. Zhang, Y., Zhou, J. and Zhou, N. (2007) Audit committee quality, auditor independence and internal control weaknesses, Journal of Accounting and Public Policy, 26(3), 300-327 